Côte d'Ivoire is said to have three outstanding characteristics - political stability, economic success and the closest relations with France of any of the Francophone ex-colonies. Political stability is not as unusual in Africa as is commonly supposed, but few countries have combined this with a development strategy based on agricultural exports and cooperation with foreign capital which has produced such rapid growth rates in GDP, GNP per capita and agricultural production.

In spite of the crisis of the early 1980s, when the country had to accept IMF and World Bank loans, the accumulated strength of the economy is such that by 1985 GDP growth was back up to five per cent p.a., and the regime was planning a 'double ouverture' of political reforms and economic reflation [Africa Research Bulletin 1987:8508; Fauré 1985]. Explanations of this success have included political stability, market oriented strategies, the influence of agricultura] interests within the state, and the unique quality of the relationship with France. But here I will be mainly concerned with state capacity - with political and administrative effectiveness.

\section{Economic Growth and State Capacity}

My concern with administrative efficacy stems from dissatisfaction with economistic explanations of Ivorian success - the suggestion that all that is needed is the correct mix of economic policies, leaving the market to take care of the rest. Ivorian aims were similar to those found in many other countries, the difference is that the planned increases did actually take place, with disappointing results in import substituting industrialisation the only exception. Bates attributes this record to the favourable policies adopted through the influence of coffee and cocoa farmers in the ruling elite [Bates 1981:95]. This analysis has been disputed [e.g. by Hecht 1983], but even if it were true, it does not tell us how such policies came to be implemented when so many other states failed. The World Bank and other neo-classical economists have attributed success to the pursuit of liberal policies (adequate incentives to foreign capital and agriculture, a stable and realistic exchange rate), but recent analyses have shown that the Côte d'Ivoire also pursues many of the 'dirigiste' policies strongly criticised in other countries [Gbetibouo and Delgado
1984:115].

Thus, although the major crops are bought and can be exported by private traders, there is nevertheless a state price-setting agency which takes a large share of the world price and uses it for state spending on services like education, state industries and expensive, capital-intensive agricultural projects. By the end of the 1970 s there were about 78 parastatals (totally state-owned enterprises), and even after a World Bank-induced purge in the 1980 s, many survived as EPNs (Etablissements Publics Nationaux), under strict public service regulation. In 1988, there were still 59 EPNs, of which 25 were of an industrial or commercial character, including major ex-societiés d'Etat such as SATMACI or SODEPALM. In addition there were 31 companies with state majority share holdings [Bulletin de l'Afrique Noire 1988; Contamin and Fauré 1987: $243,258]$. Côte d'Ivoire thus also suffers from bureaucratic elephantiasis, probably because of a similar connection with the imperatives of political patronage.

Given these similarities, we have now to look more closely at 'non-price factors' and ask why Ivorian farmers and processors were able to expand and export despite this transfer of surpluses to bureaucratic and urban interests. The relative merits of intervention vs. the free market would seem less important than whether the functionally necessary marketing system can be run efficiently and benignly, and whether 'supply side' factors are right. Do buyers give fair advances and prices and pay promptly; are there good roads and research and input services; is there an adequate supply of labour; do the imported consumer goods exist which provide the farmer with adequate incentives? These requisites can be provided by the state - indeed, given the logic of international commodity trading, some kind of monopsony seems inevitable, and the pressure for state control very strong.

The successful provision of 'non-price' incentives to producers is ultimately a function of state capacity, meaning the ability of the state to deliver essential services and maintain the conditions within which economic exchanges can flourish. Classical political economy has always recognised the facilitating role of the state, which tends to be assumed in the developed countries, but has yet to be routinised in Africa. To use 
Bates' 'collective choice' assumption, which sees the African state as a going concern, rationally responding to private interests [Bates 1983:121], is to offer a black box where there should be an explanation of how African state institutions convert political inputs into outputs. Clearly some states do this much better than others, but what does it mean to say that one state is more efficient than another - and can political science in particular provide us with a systematic and comparative analysis of African administration?

State capacity, it will be argued, is largely a question of how institutions work at the micro-level, processes which depend crucially on the routinisation of authority and compliance. These key concepts, drawn from classic administrative theory, will underpin a brief analysis of African administration, focusing on three main issues: the power and status of the administration in society at large, its relationships with other groups within the state, and the character of its internal operations.

\section{Patrimonialism and Effectiveness in African} Administration

\section{Administration and Post-Colonial Society}

Most African civil services were created only in the final years of colonial rule, and inherited a statist system based on a neo-mercantilist colonial trading economy which had exerted close control over, and heavily taxed its agricultural and mineral exporters. The independent states extended this trend and took a leading role in economic development through protection, economic and monetary regulation and direct intervention in production and service provision. This led to enormous increases in the size and number of functions performed by the civil service, and in the number of parastatal corporations. In this 'bureaucratic state', officials exercised an immense influence over resource allocation and economic opportunity; they also used state office to amass individual wealth through access to investment opportunities and to positions in foreign companies working in partnership with the state. While the power of individual officials certainly increased, it is not clear that this can be seen as an increase in the institutional power of the state administration.

\section{Administration and the State}

The colonial administration operated organisationally as a bureaucracy in the Weberian sense; but it also had autonomy as an institution and full political powers. The changes in the nature of this 'administocracy', which occurred after independence, can be linked to three major developments. First was the imposition of political accountability, which emerged with the political parties of the decolonisation period. Nearly half of African states remain party regimes today (mainly single party, as in Côte d'Ivoire); but even military rule has not always consistently inflated the power of the civil service, as the experience of Nigeria shows. Second came Africanisation, which, with the exception of Côte d'Ivoire and Malawi, was rapid and late. The first Africans promoted were a select elite, and fully socialised into British or French norms of bureaucratic behaviour. They expected to operate in the same way under the new political masters, but were often bitterly disappointed.

But the significance of Africanisation can only be understood in relation to the rapid expansion which also took place at the same time. Sudden growth meant inexperienced and poorly qualified cadres recruited according to the political demands of the new regimes and performing a wider range of new tasks. Bureaucratic values were weakly established and the new agencies were unable to resist political penetration. As a result, the autonomy of the civil service was quickly destroyed and they became 'patrimonial bureaucracies', penetrated and controlled by party, ethnic or factionally based political elites.

This is not to support the argument that a once neutral and technocratic bureacracy was 'spoiled' by politicisation, since the colonial apparatus, apart from the brief Westminster episode in the British territories, had always played a directly political role. But what happened after independence was that the civil service lost its institutional autonomy as well as its political power and, in so doing, lost its capacity to act effectively. This is consistent with the fact that individual officials increased their economic power and status, since their position was now derived from the personalist political and ethnic networks which had penetrated the administration, rather than from the civil service as an effective institutional locus of power.

\section{Neo-Patrimonialism and Administrative Effectiveness}

The effect of changes in the internal operations of the civil service, and in its relations with state and society, was to create what is commonly termed a 'neopatrimonal' bureaucratic state - i.e., a state where public offices have been appropriated by personal or social group interests and their benefits used to feed patronage networks and personal fortunes. Whilst such a system retains bureaucratic features such as hierarchical articulation of offices, division of labour and legal rule frameworks, it is, in the current literature, seen as the root cause of the economic inefficiencies and political decay of African states. Theoretically, however, the concept of patrimonialism is ambiguous insofar as it is used as an explanatory variable. Côte d'Ivoire, Kenya and Malawi are cited as examples of the benign effects of 'good' patri- 
monialism; but the misfortunes of Zaire, Uganda and Ghana are also attributed to the evils of supposedly the same phenomenon [Sandbrook 1985; Price 1984].

To accept these arguments requires an explanation of how patrimonialism can produce both administrative effectiveness and ineffectiveness, factors which in turn lead to economic and political success or failure. Either the concept of patrimonialism is so stretched as to be virtually meaningless, or certain phenomena in the good or bad cases have been misconstrued, and patrimonialism is not the most plausible explanation of the benign outcomes. In the analysis which follows, the theoretical requirements of an effective administration (defined narrowly as internal compliance with organisationally set goals and procedures) are measured against the predicted impact of patrimonial principles, focusing particularly on the practical consequences of failures of compliance on economic development and political stability, e.g. on the implementation of feeder road programmes, the operation of marketing systems or the ability to collect taxes. From this it should be easier to disentangle the 'good' or 'bad' effects of patrimonialism from other explanations of what creates administrative effectiveness, and to distinguish between the direct impact of patrimonialism on organisations and its indirect impact, further down the chain of causation, on economic growth.

\section{(i) Appropriate Role Definition}

Whilst all organisational relationships are a mixture of formal and informal roles, it is the formal which define the fundamental structure of behaviour. Yet patrimonialism subverts formal roles because it makes compliance predominantly a matter of personal ties - performance becomes erratic and arbitrary when organisations are staffed on nepotistic principles and permeated by clientelistic networks. Further, unclear role definition (perhaps simply the result of rapid and ill-planned expansion) will lead to incompetence because officers are unsure of their discretion and jurisdiction. Especially in new organisations such as African parastatals, set up with poorly defined and of ten impossible tasks to perform, and staffed by officers with political debts to repay, the definition of roles may itself become a source of struggle and conflict of authority.

\section{(ii) Incentives}

The pursuit of individual advantage is accepted in organisations, but incentives and sanctions must exist which ensure that individual motivation is made to serve organisational purposes. But in Africa sanctions may fail because hierarchies are subverted by patrimonialism, whilst pay-offs may be determined in ways that are subversive of organisational coherence and purposes.

\section{(iii) Organisational Norms and Authority}

The complexity of large organisations is such that effective performance can only be assured where officials feel a normative commitment to organisational purposes. The very concept of a formal role or office articulated hierarchically with other offices depends on the idea of a public or organisational realm divorced from private interests. The authority of the hierarchy of offices derives from the normative value attached to the organisation itself and to its purposes [Beetham 1987:38]. It is sufficient that officials begin to defend the agency's interests as if they were their own; in time, an 'agency ideology' emerges, involving a recognition of its values, style and justification of its purposes. In the most highly institutionalised bureaucracies, there is an internalisation of legal norms of authority and thus an acceptance of the Weberian concept of 'public duty' and accountability to the legitimate political order. But the crucial distinction is that between the authority of an office which is public and produces commitment to organisational goals and procedures, and personal authority, which leads to the breakdown of its coherence and purposes and eventually to total paralysis. Most African administrations have failed to develop these bureaucratic values, and therefore cannot act effectively.

\section{(iv) Accountability}

In the last analysis, discipline in the civil service must be validated by accountability to a ruling group or institution. But commonly, patrimonial political regimes, military or otherwise, sanction only systems of plunder based on competitive patron-client networks. African civil services have therefore lost the ability to act as autonomous institutions and to challenge political decisions on professional or technical grounds. Their weakness is not just a product of external political control, but of a lack of accountability to an agency which will sanction behaviour supportive of organisational values and coherence. Indeed, political control may be positively destructive insofar as it sets rhetorical or unrealistic goals (as in the vogue for formalistic decentralisation of rural development), or vitiates policies through corruption which administrators cannot prevent or are invited to share.

Thus the principles of patrimonialism seem to undermine or contradict the effectiveness of African administrations, particularly as regards their need for authority and organisational commitment. How is it, then, that a state such as Côte d'Ivoire, which appears to have a relatively effective bureaucracy and has enjoyed ususual economic growth can be characterised as patrimonial? Only a more direct consideration of the Ivorian case can reveal whether the patrimonial analysis is appropriate or helpfut in explaining such an outcome. 
Patrimonialism and Effectiveness in Côte d'Ivoire

\section{The Political Context}

The Ivorian political elite dates back to the early 1950 s, and the one-party state led by HouphouetBoigny and the PDCI has survived virtually unchallenged since then. Ethnicity as a potential source of conflict has been successfully managed by techniques of cooptation and balancing which discourage ethnic mobilisation. The executive presidency controls both government and civil service and, through the party, the National Assembly and Economic and Social Council. Until 1980 elections were uncontested. Since 1980 competition within the one-party framework has been introduced, producing some degree of renewal. This has maintained rough ethnic balance, but the dominant factor has been the dominance and continuity of a core elite which links the main institutions of government through multiple office-holding. According to Bakary [1984:24] between 1957 and 1980 only 320 individuals have held the 1,040 positions available in these institutions; in 1986, all the members of the PDCI Executive Committee were also Ministers in the new Cabinet.

The Presidency is the source of control and patronage in the top civil service, the parastatal sector and industries financed by state and private capital. Top members of the elite are commonly given lucrative positions with foreign companies, and the country also has a problem of corruption, as periodic scandals reveal - for example when the Mayor of Abidjan was forced to flee the country after embezzling CFA francs $26 \mathrm{mn}$ from the National Agricultural Development Bank [Africa Rescarch Bulletin 1986:7979]. This patronage system has, of course, been greatly aided by the economic growth which has allowed potential sources of opposition to be absorbed through the expansion of state-financed job opportunities and the relatively. wide distribution of benefits among important indigenous interests. Observers differ, however, as to whe ther the regime has survived purely through Houphouet's astute manipulation of payoffs, or whether, as close observers claim, the core elite has been sufficiently institutionalised to produce a stable succession.

We may now consider the extent to which the operation of the patronage system run by the President and ruling group has contributed to organisational effectiveness, by looking first at the nature of the political elite which it has created. We shall then relate elite characteristics to the desiderata specified in our model of administrative effectiveness: the development of bureaucratic norms, the emergence of organisational loyalty and commitment, and the support, or otherwise, of the norms set by the political order.

\section{The Ivorian Political and Administrative Elite}

This elite has become increasingly technocratic, highly educated and dominated by those who have pursued civil service careers. Very high percentages are graduates, mainly from science and technical backgrounds, and almost all ministers in 1980 were ex-civil servants [Bakary 1984:38-46]. In the field administration there has been an increase in recruitment from the military; in the parastatals it seems that older party militants have been gradually displaced [Fauré and Medard 1982:136]. Secondly, this elite has been extremely stable and has changed very gradually despite the influx of technocrats. In 1981 , one quarter of ministers had held office for over 10 years [Bakary 1984:38-46]. Thirdly, a very significant role is still played by expatriates in managerial and technical positions. The present European population of 50,000 has grown from about 10,000 since independence in 1960 . In the mid-1970s, 48 per cent of middle management jobs and 80 per cent of jobs requiring degrees were filled in the private sector by expatriates [den Tuinder 1978:294-6]. In the administration, expatriates appear to play a key role as technical advisors assigned to double up in positions occupied by Ivorians.

This high expatriate presence is a product of the country's exceptionally close relationship with France, where strong political links have been cemented with preferential aid and trade agreements, the despatch of large numbers of students to French universities, and a continuing flow of French investment. Some commentators therefore imply that the country's relatively high levels of bureaucratic performance are merely the result of being run by the French [Jackson and Rosberg 1982:146; Sandbrook 1985:120].

On closer examination, however, it would seem that the position is not that simple. First, the bulk of high level manpower is involved in import-substituting industrialisation in foreign firms. (in 1979, 42 per cent of cadres in the private sector were expatriate - see Côte d'Ivoire Le Plan Quinquennial de Développement 1981-85, Tome III:606.) Attracted to the country by generous incentives, they are employing highly paid Europeans in what is probably the most featherbedded and economically unsuccessful sector of the economy! In the public sector we know that in the 1970 s 75 per cent of expatriates were teachers, and that 80 per cent of all secondary school teachers were French. But there is little agreement on the actual extent of European dominance in the parastatals and the civil service. 27 per cent of management in the parapublic sector was expatriate in 1979 [Lecallo 1982:93], but in the civil service proper, political sensitivity is such that top posts are Ivorianised and Frenchmen play the role of 'supernumary' advisors (with the notorious exception of the Direction Centrale des Grandes Travaux (DCGTx), run by Houphouet's 
most trusted French lieutenant [see Fauré and Contamin 1987:215]). One interpretation is that the French are indeed playing the role of loyal mercenaries.

\section{Bureaucratic Norms}

To what extent does this highly educated elite, drawn mainly from the civil service and military and permeated by the influence of French managers and advisors, show a commitment to bureaucratic values? This is best answered by analysing the extent of its acculturation to the bureaucratic norms of preexisting (i.e. colonial) administrative institutions. The most important influences on this process, tempering the possible consequences of patrimonialism, have been policies on Ivorianisation and education.

First, Ivorianisation has been very slow and based on qualifications, whilst the educational system has produced a relatively small stream of readily recruitable graduates educated to French metropolitan standards. The government has spent more on education than other African states, but while primary provision is now universal, only 24 per cent of the final year go on to secondary school, and only about 500 Ivorian graduates are produced each year from the University of Abidjan and institutions overseas. In secondary schools, standards of provision and institution are set by predominantly French teachers and lavish levels of French aid; in the University there are high repeat and failure rates. The World Bank has criticised the system as expensive and inappropriate, but it has certainly produced an academically competent elite fully socialised into French ways of thinking.

This elite was then gradually inducted into a system in which there was at first room for everyone, even though the pace of Ivorianisation was slow. Only after 1977 did pressures in the middle ranks produce an Ivorianisation policy, and even then the commitment was to do so as fast as possible without 'disrupting production or growth' or 'hindering efficiency' [den Tuinder 1978:153]. Indeed, in the public sector the Ivorianisation plan was apparently hit by shortages of manpower, caused by the greater attractiveness to Ivorian graduates of private sector employment. Thus the educational system was perfectly adapted to ensure that those recruited into the civil service and parastatals would not challenge prevailing norms and practices, but would maintain the continuity of colonial institutions already powerfully underpinned by the continuing expatriate presence.

Given a natural tendency towards organisational inertia, the longer a structure survives the more difficult it is to disrupt. In Côte d'Ivoire the deliberate policy of maintaining its continuity with the colonial past meant that the disintegration and weakening of bureaucratic values and procedures, caused elsewhere by rapid Africanisation and political penetration, would have been avoided. The significance of the expatriate presence did not derive from the occupation of executive positions as such, but from the continuity of institutional procedures and 'agency ideologies' which they ensured: And this spilled over from the civil service into the more successful parastatals such as SATMACI, the key agricultural service agency for export crops.

\section{Organisational Loyalty}

How far, therefore, has the character of the elite created a sense of organisational interest separate from individual interest? First, its remarkable stability and ability to adapt and incorporate new entrants will have induced loyalty. Cohesion, continuity and success will produce loyalty even if 'only' out of the elite's instinct for the preservation of its system.

Second, and perhaps more important, is the 'Houphouet-Boigny' factor, based on the Presidency not as a purely personalised system but as the core of an interlocking set of institutions. The executive office - the Secretariat General plus civil and military cabinets - controls ministers, parastatals, the line hierarchy of the field administration, the party machine and the National Assembly. The Party, far from having faded away, is a central channel for elite recruitment and trouble shooting in the regions. It operates as a channel both for enlarging the ruling coalition and as a parallel structure for enhancing Presidential control, and is therefore an important $\operatorname{cog}$ in the country's administrative machinery. The President himself, although undoubtedly a rich and powerful patron in his own right, cannot directly control all aspects of the state, and has been able to rely on 'des collaborateurs solides' [Medard 1982:63-4, Zartman and Delgado 6-8].

Thus the role of Houphouet-Boigny could be said to be to create a 'loyalty principle' so that loyalty to the leader can be invoked at all levels of the administration - a personalisation of loyalty to what is in effect 'the system'. It is this form of loyalty which is constantly renewed through co-optation and personal patronage, through the President's dialogues and through patronage of localities or pork barrel politics. The post 1980 electoral competitions therefore strengthened the system, since large numbers of the old guard could be disposed of without challenging the regime at all. Houphouet's own caution about his succession is linked to his desire to maintain elite cohesion.

But commitment is also maintained through discipline, which depends not only on loyalty to the President but also on very concrete control structures. Thus the field administrative system has enormously expanded its capacity for detailed control through the multiplication and subdivision of administrative areas, subjecting smaller and smaller areas to central control. This also 
fulfils the needs for political representation, and has been accompanied by an increase in the number of deputies in the National Assembly.

As party leader, the President also embodies the national myths associated with the 'struggles' of the $1950 \mathrm{~s}$, but this Bonapartist claim to popular legitimacy is reinforced very pragmatically by targeting particular groups for co-optation - urban elites, export farmers, regional and ethnic interests, business groups. "Co-optation and purchase are habit forming', writes Zartman, 'and are constantly renewed by the pork-barrel principles for success operated in the party and Assembly in their interaction with the administration' [Zartman and Delgado 1984:11]. Hence 'loyalty to HouphouetBoigny' is a concept which involves deeper meanings than simple personal admiration. Both rewards and sanctions for effective role performance are more effectively provided than in other African states.

Thus career incentives - and possible punishment mean that it has not been possible to flourish without loyalty to the effective working of the state institutions within a system represented by the person of the President. To call this nothing more than a personalist system is perhaps to underestimate it, since similar principles can be seen at work even in the highly institutionalised systems of Britain, France or the USA! What could be developing is the kind of social discipline which Sandbrook argues can only come with the rise of a 'hegemonic class' [Sandbrook 1985:118].

\section{State Capacity and the Political Order}

As argued earlier, administrative effectiveness must be sustained by the norms and goals set by the political order. The Ivorian civil service is clearly controlled by a deeply entrenched political elite, but, although formal distinctions exist between political and administrative spheres, the foregoing analysis shows that there is considerable interpenetration of political and administrative elites. The regime has pursued policies intended to maximise economic growth at any cost - including foreign ownership of large areas of industry, foreign domination of education and management, slow rates of Ivorianisation, and strongly pro-French political and economic policies. But all of this has only served to strengthen the technocratic outlook of the political elite which it shares with the civil service, and to ensure that the patrimonial elements in the system have not been allowed to override the commitment set from the top to bureaucratic values, effective role performance and the implementation of the economic programme. This commitment has probably been so strong as to override resentments lower down the administrative hierarchies at the slow pace of Ivorianisation, and at the President's unshakeable attachment to France.
Further, the maintenance of this commitment has itself been linked to the relative success of the economic programme, and especially in agriculture and agri-processing. Not only was HouphouetBoigny's authority totally behind the vigorous programmes for coffee, cocoa, palm oil, cotton, rice and sugar, but these (with the exception of sugar) then secured very positive results, making it difficult to challenge the general values and outlook of the leadership. This growth also permitted the expansion of the parastatal sector which, with its associated patronage, served for a time to enhance elite control. Characteristically, however, when this expansion of patronage threatened to get out of control, the debt crisis of the early 1980 s served as an appropriate justification for the purging and reintegration of much of the parastatal sector into the central bureaucracy, under strengthened legal controls [Contamin and Fauré 1987:215-30].

Distribution of the benefits of economic growth amongst significant social interests, rural and urban, has also broadened the basis of the regime and thus enhanced the accountability demanded of administrative agencies. The economic opportunities offered at the elite level have created a cohesive 'bourgeoisie d'Etat' similar to the 'patrimonial' class found in other African states, but one with a much stronger commitment to imported technocratic values and a higher degree of political unity and cohesion. The most serious frictions in society relate to the conflict between the worst educated Ivorians and the many foreigners involved in unskilled work and petty trade. But these tensions lead to xenophobia rather than to anti-elite feelings, and tend to consolidate the sense of privilege enjoyed by all Ivorians. The regime can thus draw support from both elite groups and broader social and economic interests, and on this basis, can sustain its ability to impose its own vision of appropriate values on the administrative machinery.

\section{Conclusion}

In Côte d'Ivoire a 'virtuous circle' was established in which economic growth and political stability reinforced each other. But it is not enough to explain one in terms of the other, because that begs the question of how the 'correct' policies came to be implemented in a statist environment which elsewhere is said to preclude efficiency and growth. Neither does it explain how the fruits of economic growth have produced stability, when they could just as easily have produced conflict over the spoils. Further, the dependence on foreign investment and labour seemed to challenge not only African conventional wisdom but the 'dependency theory' assertion that the dominance of foreign capital would lead to 'underdevelopment' rather than to progress. 
It has been argued that the achievement of Ivorian policy goals was strongly associated with 'non-price' and 'supply-side' factors - with state capacity and with the ability of developmental institutions to deliver the conditions and services required for growth in production. State capacity at the micro level has been defined as a function of the ability of an organisation to achieve compliance with internal authority and formal role functions. This in turn is related to a commitment to organisational goals and the emergence of 'agency ideologies', as well as to the context within which accountability is demanded.

We clearly need more information on how individual agencies operate to achieve these ends in Côte d'Ivoire and elsewhere. But the general analysis presented in this article shows that although the President does operate a patronage based system of appointment and favour, the values sustained through it are conducive to bureaucratic role performance and organisational (as opposed to individual) loyalty and commitment. Clearly patrimonialism can coexist with bureaucratic effectiveness - as the historical examples of the English Navy or the Colonial Office should have taught us. But it is misleading to causally relate the so-called 'benign-patrimonialism' of the Ivorian President to either state capacity or economic growth. The only positive contribution of the patrimonial system to these outcomes is probably its indirect role in the creation of agency loyalties. The determining factors in the Ivorian case were, first, the unusual degree of organisational continuity between pre- and post-independence administration, a continuity supported by the education system and the policy of gradual Ivorianisation. Secondly, the powerfully entrenched ruling elite was able to enforce these policies, and their accompanying technocratic values, partly because its own formation and composition was unusually bureaucratic and partly because the political leadership showed an ability to co-opt new elements and balance benefits so that elite cohesion and some elements of popular support could be maintained. Once the material benefits of this system were demonstrated, then the policy commitments of the elite became self-sustaining and the 'virtuous circle' was established.

\section{References}

Bakary, T., 1984, 'Elite transformation and political succession', in I. Zartman and C. Delgado (eds.), The Political Economy of Ivory Coast, Praeger, New York

Bates, R., 1981, Markets and States in Africa, University of California Press, Berkeley

-1983, Essays on the Political Economy of Rural Africa, Cambridge University Press

Beetham, D., 1987, Bureaucracy, OU Press, Milton Keynes

Bulletin de l'Afrique Noire, 1988, no. 1403, 7 April

Contamin, B. and Fauré, Y.-A., 1987, La Restructuration des Entreprises Publiques en Côte d'Ivoire, Rapport au CNRS, Paris

Côte d'Ivoire, République de la, 1983, Plan Quinquennialde Développement $198 /-5$, Tome III

den Tuinder, B., 1978, Ivory Coast: the challenge of success, Johns Hopkins Press, Baltimore

Fauré, Y., 1985, 'Nouvelle donne en Côte d'Ivoire', Politique Africaine, 20

Fauré, Y. A. and Medard, J. F., 1982, Etat et Bourgeoisie en Côte d'Ivoire, Editions Karthala, Paris

Gbetibouo, M., and Delgado, C., 1984, 'Lessons and constraints of export crop led growth: cocoa in Ivory Coast' in I. Zartman and C. Delgado (eds.), The Political Economy of Ivory Coast, Praeger, New York

Hecht, R., 1983, "The Ivory Coast economic "miracle": what benefits for peasant farmers?', Journal of Modern African Studies, 21

Jackson, R. H. and Rosberg, C. G., 1982, Personal Rule in Black Africa, University of California Press, Berkeley

Lecallo, D., 1982, Les Entreprises Publiques en Côte d'Ivoire, Ministère de la Coopération et du Développement, Paris

Medard, J-F., 1982, 'La regulation socio-politique', in Y-A. Fauré and J-F. Medard, op. cit.

Price, R., 1984, 'Neo-colonialism and Ghana's economic decline', Canadian Journal of African Studies, 18

Sandbrook, R., 1985, The Politics of Africa's Economic Stagnation, Cambridge University Press 